\title{
The effect of agricultural land recovery on people's livelihoods in the context of urbanization in Vietnam
}

\author{
Thanh Thuy Cu${ }^{a}$, Tuan Anh Nguyen ${ }^{a}$, Phuong Nguyen Thi Lan ${ }^{a}$ and Thi Yen Le ${ }^{a^{*}}$
}

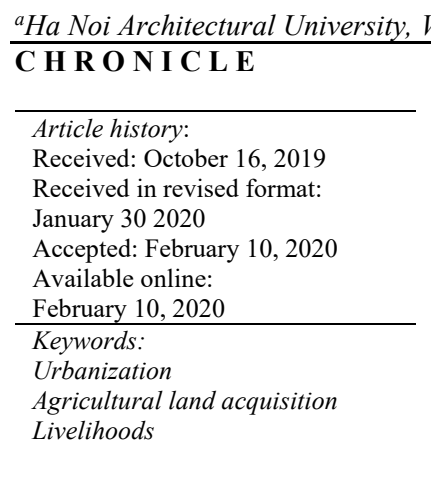

\section{A B S T R A C T}

This study was designed to analyze the influence of agricultural land acquisition on people's livelihoods in the Urbanization context in Vietnam. The findings show that agricultural land acquisition due to urbanization opens up new job opportunities for households at the same time, households also have opportunities to expand and change their livelihood strategies through new investment activities. However, the acquisition of agricultural land also causes negative influences on households, some workers who fail to meet the job requirements may remain unemployment, which means it negatively affects the households' income. The results of the examination are considered as the basis for the research team to propose recommendations to contribute incomes for people.

\section{Introduction}

Urbanization has become an inevitable trend of the development process not only from the perspective of each country but also from the perspective of localities. It promotes economic development for the urbanization process. The history of urbanization in the world has indicated that industrialization could promote urbanization process. In fact, the process of urbanization in Vietnam in recent years has shown that urbanization leads to industrialization. The central reason of this phenomenon is the pressure on housing. The "irregular" development causes urban systems in Vietnam called "urban diseases" in terms of architecture, transportation, domestic wastewater, and self-reliance due to other social security issues. According to the statistics of the Ministry of Construction, currently, Vietnam has 819 urban areas, the coverage rate of urban construction general planning reaches $100 \%$, subdivision planning reaches about $78 \%$, detailed planning is about $39 \%$ and rural construction planning has achieved at $100 \%$. At the same time, according to the statistics of the Ministry of Planning and Investment, by the end of 2018, Vietnam has built 326 industrial parks out of 463 planned industrial parks, total natural land area of these industrial parks are approximately 93 thousand hectares, in which 56,000 hectares of industrial land can be leased (accounting for about $66 \%$ of the total natural land area), industrial parks throughout the country have attracted about 7500 domestic investment projects with a total registered capital of about 970 trillion dong and about 8000 foreign-invested projects with a total registered capital of about 145 billion USD. The occupancy rate of industrial parkland area is about 73\% (Department of Economic Zone Management, Ministry of Planning and Investment, 2019). When the process of industrialization and urbanization took place, besides the achieved results in terms of economy, employment creation and social progress, several negative issues have also appeared and a large area of agricultural land has been acquired. According to data from the Ministry of Agriculture and Rural Development, an average of 73,000 hectares of agricultural land is acquired each year, affecting about 2.5 million people and for every 1 ha of land acquired, 10 people lost their jobs (Thuận et al., 2018), which has greatly affected and changed the people's livelihood strategies. Therefore, this study was carried to analyze the effects of agricultural land

* Corresponding author.

E-mail address: lethiyenktdt@gmail.com (T. Y Le) 
acquisition on people's livelihoods in the context of urbanization in Vietnam, however, the angle of approach of this study is the economic perspective, the study will look at people's adaptability when living conditions change and how will the land acquisition affect livelihoods of the people (specifically income).

\section{Overview}

In terms of increasing agricultural land acquisition due to urbanization and industrialization in the suburbs of major cities, Vietnamese researchers have tried to find answers about how the loss of agricultural land affected the income of rural households. In these studies, quantitative or descriptive statistical methods were used to analyze data. Secondary data were collected from various publications in Vietnam, Nguyen et al. (2006) showed that over the past decades, Vietnam has experienced rapid urbanization and industrialization in suburban areas, as a result of this process a large number of rural households have lost their agricultural land to the development of industrial parks and urban areas, and many of them have fallen into the poverty. However, several case studies in suburban areas of Ho Chi Minh City and Hanoi show the mixed effect of the acquisition of agricultural land to the income of local people. When studying the case in a village on the outskirts of Hanoi, where twothirds of agricultural land was lost due to urbanization from 1998 to 2007, Nguyen Van Suu (2009) found that many households had benefited from their proximity to universities and central cities. Income from rental houses for students and migrant workers have emerged as the most important source of income for the majority of households. However, some other households face insecure lives because they do not have rooms for rent and many landless farmers have become unemployed, especially the elderly and lower educated farmers. Using quantitative methods to access household livelihoods to investigate the impact of these factors on income and expenditure of households in the peri-urban areas of Tuyen and Van Huong (2014) provided evidence that agricultural land had an impact on household income when losing agricultural land hurts farm household income and it created a positive impact on the household when employment in non-agricultural sectors increased. There are several studies on the direction of creating livelihood strategies for people who lose land in the process of urbanization and the process of building industrial parks (e.g. Tuyen, 2013; Nghi \& Van Trinh, 2011; Tuyen \& Van Huong, 2014; Benayas et al., 2007; Bryceson, 1996; Jansen, et al., 2006). This study has determined the status of household income after losing land, people's employment status, and analysis of factors affecting the livelihoods of people losing land. The factors selected for analysis have gained significant similarities in these studies such as educational level, the number of employees, the gender of household head, area of farmland land, household members join social organizations, access to credit, etc. Tuyen (2013) quantified the relationship between the factors that affect people's income and using data collected from 477 households who lost their land in suburban Hanoi, the author studied the relationship between the factors affecting people's income using the Multinomial Logit model. People's income was divided into income in agriculture, income from a business, income from hired working jobs requiring low qualifications, low skills, income earned from doing jobs requiring qualifications and skills and non-labour income. Besides, some studies have been accomplished towards the influence of industrialization on the livelihoods of people losing land, for instance, Paul and Sarma (2013) assessed people's satisfaction with infrastructure when industrial parks are built and studies the impact of such infrastructure development on people's lives. They found people had a good assessment of the infrastructure system after the industrial park was built, the ability to access roads, electricity and clean water with people was better. However, there was a difference in the results of this study that a better infrastructure system could lower people's income. This result is contrast to other studies such as Thuận et al. (2018) amd Nghi and Van Trinh (2011).

\section{Research Methodology}

\subsection{Data collection methods}

Based on the questionnaire of the General Statistics Office in 2006 (GSO, 2006), the authors designed a household questionnaire to collect quantitative data for research. The data in the questionnaire included: household characteristics and factors affecting household income. The authors distributed 1,000 questionnaires and managed to collect 630 questionnaires corresponding to 630 households selected for interview. These data were collected and entered into excel software, 19 questionnaires did not have enough data and was removed by the research team, leaving 611 questionnaires to meet the requirements. Primary data were collected from the beginning of June to the end of October 2019 using the questionnaire through direct interviews with the head of the household along with the presence of other family members. The author uses direct survey method to collect information about households and uses direct survey method in combination with collecting data related to household income and employment. The descriptive statistical results are shown in Table 1:

\section{Table 1}

Descriptive statistics for observations

\begin{tabular}{|c|c|c|}
\hline Criteria & 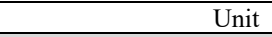 & Frequency \\
\hline 1. By gender & People & 611 \\
\hline 1.1. Male & & 372 \\
\hline 1.2. Female & & 239 \\
\hline 2. By age & People & 611 \\
\hline Under 35 & & 122 \\
\hline From 35 to $<45$ & & 165 \\
\hline From 45 to $<55$ & & 216 \\
\hline$>=55$ & & 108 \\
\hline
\end{tabular}

Source: Author's survey results 
Moreover, the research also uses a focus group discussion method to collect supplementary data for analyzing quantitative data. Group discussion method was used by the author to collect data on people's opinions and views on people's assessments regarding the impact of urbanization on their lives, namely, their income and their positive/negative effects. Time for group discussion was from the January 2, 2019, to prepare for group discussions. The authord prepared guiding for group discussion, where the authors specified the information array required for exploiting and finding out to have comments on objective reviews of the household on the impact of agricultural land acquisition on people's livelihood. Specifically, the authors wished to receive the opinions of the participants in the group discussion on their ideas on the following problem areas as follows: how does family income changes, how do jobs change, services that the family enjoys, new livelihood strategies etc. of households. The recommendations of the family are used to further strengthening the livelihoods of households. Opinions and sharing of group discussion are specifically and fully recorded by the authors and saved in the data file. The results of group discussions will help the authors in analyzing and having a more multidimensional perspective, effective complement for quantitative analysis.

\subsection{Modeling method}

Using the quantitative data collected, the research team used a quantitative model to examine the influence of agricultural land acquisition on people's livelihoods in the setting of urbanization:

Dependent variables $(Y)$ :

The household's livelihood: the author uses the income scale; the household's income scale is the total income earned in a year in terms of Million VND / year.

Independent variables:

+) The area of agricultural land has been revoked (S_landloss): The area of land that households acquired when urbanizing. The unit of calculation is in terms of square meter. According to a study by Nguyen Van Suu (2009) when a household loses land, a part of people will have an income increase when they have enough resources and take advantage of the process of industrialization, urbanization. However, a part of other people will face an insecure life because when losing land they will be unemployed. According to research by Nguyen et al. (2006), when losing agricultural land, people will fall into poverty, loss of land has negative effects on the income of the people.

+) New investment (Invest): This is the actual investment of households for activities such as building houses, investing in business and service, etc. in million VND/year. According to Le et al. (2020), an increase in investment will lead to household income increase.

+) Transportation system (Road): As the evaluation variable of households on the transport system after the cities were built, it returns 1 if the answer is the transport system is very bad, returns 2 if the transport system is bad, returns 3 if the answer is a normal transportation system, returns 4 if the transport is good and return the value 5 if the transport system is very good. In the study of Paul and Sarma (2013), the authors pointed out that, better infrastructure system reduces people's income.

+) The number of jobs increased after farming land has been revoked (Employ): the number of jobs calculated for each household after the agricultural land be recovered, additional jobs may occur when families create jobs by themselves or family members apply for new jobs in enterprises and production units. The unit of calculation is the Employee.

+) The number of unemployed workers when agricultural land is acquired (Unemploy): This is the number of employees in each household who is unemployed when land is acquired because they cannot find new jobs. Calculation unit: employees.

\section{Control variables:}

The number of employees in the household (Labor): Reflecting the actual number of employees in the household who can participate in production and business activities to generate household income. In quantitative research results, the authors mentioned the cost of living of the family (Cost) after urbanization took place, however, the focus of the study was on the effects of agricultural land acquisition on people's livelihoods, so the authors did not focus on this variable in the study. So, the research model has the form:

$$
\mathrm{Y}_{\mathrm{i}}=\mathrm{a}+\mathrm{b}_{1}\left(\mathrm{~S} \_ \text {landloss }\right)+\mathrm{b}_{2}(\text { Cost })+\mathrm{b}_{3}(\text { Invest })+\mathrm{b}_{4}(\text { Road })+\mathrm{b}_{5}(\text { Employ })+\mathrm{b}_{6}(\text { Unemploy })+\mathrm{b}_{7}(\text { Labour })+\mathrm{U}_{\mathrm{i}}
$$

\section{Findings}

By interviewing 611 households whose agricultural land is recovered during the urbanization process, the authors considered both positive and negative impacts of agricultural land acquisition on people's livelihoods in the process of urbanization. Table 2 shows the results of some basic statistics. 
Table 2

Descriptive Statistics

\begin{tabular}{lcccc}
\hline & Mean & Maximum & Minimum & Standard Deviation \\
\hline Labor & 2.716858 & 7 & 0 & 1.311998 \\
Invest & 43.87758 & 480 & 0 & 86.41746 \\
Cost & 66.03764 & 187 & 12 & 31.06524 \\
Road & 2.659574 & 4 & 1 & 0.89185 \\
S_landloss & 874.0115 & 10400 & 40 & 1283.554 \\
Employ & 1.263502 & 4 & 0 & 1.021551 \\
Unemploy & 0.801964 & 4 & 0 & 0.96244 \\
Y & 127.6592 & 600 & 0.5 & 97.03157 \\
\hline
\end{tabular}

Source: Processing results from survey data

The survey results show that the average income of the selected households interviewed was $127.6592 \mathrm{million}$ VND/year, according to research by Nguyen Van Suu (2009), Households who lose their land will receive a relatively large amount of compensation, which households can adapt to and make good use of this money along with opening up employment opportunities from non-farm activities such as services, motels for workers etc. That will become a new livelihood strategy for the people. The results of research also show that the investment of households was relatively high, the average value was 43.87758 million VND per year, this amount of money was invested by households in some investment items such as building houses for hiring workers, investing in service activities, etc. This is also one of the reasonable trends in country's industrialization and modernization. The average number of additional jobs was 1.263502 per household, this phenomenon was partly because land-losing households have priority in recruiting into production and business establishments, enterprises in industrial parks. Besides, a part of their family members creates new jobs through the construction of inns, they are self-employed. The transport system according to the people's assessment is at an average level, with the average score of the people being about 2.65974 points. This is not a good number, but it also partly meets the level of satisfaction of the people with this item after the cities are formed. It gives to helping people be more convenient in the process of carrying out their livelihood activities, opening new directions and livelihood strategies for people. Also, when recovering agricultural land of households, in addition to creating jobs for people living around urban areas, there are negative impacts, when a part of the people is not able or is not interested. With new environmental changes, no new livelihood strategy to stabilize their lives, a part of the members of these households were unemployed, resulting in it shows that the number of unemployed labors after the acquisition of agricultural land was relatively large which is about 0.8 laborer / household. Table 3 shows the results of regression analysis.

Table 3

The results of regression estimate

\begin{tabular}{|c|c|c|c|c|c|c|c|c|}
\hline & & \multicolumn{2}{|c|}{$\begin{array}{l}\text { Unstandardized } \\
\text { Coefficients }\end{array}$} & \multirow{2}{*}{$\begin{array}{c}\text { Standardized } \\
\text { Coefficients }\end{array}$} & \multirow[b]{2}{*}{$\mathrm{T}$} & \multirow[b]{2}{*}{ Sig. } & \multicolumn{2}{|c|}{ Collinearity Statistics } \\
\hline \multicolumn{2}{|c|}{ Model } & $\mathrm{B}$ & Std. Error & & & & Tolerance & VIF \\
\hline \multirow[t]{8}{*}{1} & (Constant) & 10.81007 & 10.33071 & & 1.046402 & 0.30 & & \\
\hline & Labor & 4.343515 & 1.719373 & 0.05873 & 2.52622 & 0.01 & 0.967489 & 1.033603 \\
\hline & Invest & 0.13578 & 0.02624 & 0.120927 & 5.174615 & 0.00 & 0.957493 & 1.044394 \\
\hline & Cost & 0.390849 & 0.077399 & 0.125133 & 5.049783 & 0.00 & 0.85159 & 1.174274 \\
\hline & Road & 5.932635 & 2.507003 & 0.054529 & 2.366425 & 0.02 & 0.984826 & 1.015408 \\
\hline & S_Landloss & 0.060597 & 0.001749 & 0.80159 & 34.65397 & 0.00 & 0.977301 & 1.023226 \\
\hline & Employ & 7.685698 & 2.252523 & 0.080915 & 3.412039 & 0.00 & 0.929808 & 1.07549 \\
\hline & Unemploy & -6.44866 & 2.474592 & -0.06396 & -2.60595 & 0.01 & 0.867956 & 1.152132 \\
\hline
\end{tabular}

The results of Table 3 indicate that all variables in the study are statistically meaningful when the level of significance is one percent and all factors affect household livelihoods to different degrees. For the variable of the area of land acquired (S_landloss), the coefficient of the variable of the area of land to be recovered is 0.80159 , which means that when the people whose land is recovered, their income increases. The reality shows that people who have money to compensate for the loss of land due to urbanization have changed to a new way of livelihood: from farming to trading goods, providing services or building inns for workers.

New investment (Invest): The examination results of the author support the opinion of Le et al. (2020) and the coefficient of the new investment variable is positive and has a value of 0.120927 . When the new investment is increased by 1 thousand $\mathrm{VND}$, the income of the people will be increased by $0.356 \mathrm{VND}$.

Transportation system (Road): Research findings show that better transportation system increases people's income. With the coefficient of the traffic system variable after urbanization is 0.054529 , the research findings of the author are not compatible 
with the views of Paul and Sarma (2013), from the author's point of view when urban formation and development, transportation system will be upgraded to meet the demands of people who are moving to other places, this is completely favorable for business and business households.

As urban centers are built and developed, apartments and more high-rise buildings are formed, more factories, enterprises also appear, the demand for transportation systems ensure circulation and meet the requirements of the enterprises is also increase. Therefore, not only the transportation system but also other infrastructure systems are also invested by local governments as well as governments. People in these areas benefit greatly from the changes of the transport system in particular and the infrastructure system in general. The transport system is more modern, people profit from this system through the exchange of goods between localities, a part of household's supply products to the market when the transport system is convenient, the distributors come back to the locality to buy the products. The favorable transport system has helped localities improve the investment environment, thereby encouraging investment attraction from enterprises, when there are production and business establishments and enterprises coming to the localities will contribute to expanding employment opportunities for local people.

Number of new employment (Employ): The number of jobs increases as the city grows, companies open up more, since then the demand for human resources increases, when new jobs are created, this contributes to people's income. The coefficient of this study variable is 0.080915 and the author's research findings also support the previous studies of Tuyen (2013), Tuyen et al. (2014).

Number of unemployed laborers due to agricultural land acquisition (Unemploy): It is undeniable that, for households whose land is acquired, there are households who will be unemployed because they have not caught up with the opportunities created. As a result, the number of unemployed labors remains unchanged, the income of household's decreases and at the same time, the relationship between unemployed workers upon acquisition of agricultural land and household income is on the opposite side. The author's study results also support previous studies of Nguyen Van Suu (2009), Le et al. (2020).

When families whose agricultural land is acquired will face employment problems, people will have to develop a new livelihood strategy. People of working age are accepted by enterprises and factories to have stable jobs and income if they meet the requirements of skills and qualifications. However, for somebody outside the age group and those who do not meet the recruitment needs, they need to adapt to changing jobs accordingly, thus creating unemployment for a part of the labor force. In the past, laborers working toward agriculture-related jobs did not require any qualifications, they worked according to the habit and were taught from generation to generation.

\section{Some recommendations}

Based on the research findings, the writer proposes several recommendations to change people's livelihoods in a positive way for a group of people whose agricultural land has been acquired due to urbanization. Creating stable jobs for people with land acquisition, the goal of this proposal is to create jobs for people with land acquisition, when people have a stable job, their income and standard of living will be stable. To implement this solution, it is necessary to: Improve the quality of human resources and labor discipline of people whose land is acquired. It is also important to provide capital support and orientations for households investing in production, business and career change. For households, difficulties in capital for production and business is one of the biggest difficulties, the lack of capital to implement the plans will obstruct households in implementing. Currently, the production and business plans, thereby causing difficulties in stabilizing the people' lives. Furthermore, a part of the people do not have or do not have the right direction in using the capital of the family effectively, causing waste of capital, thereby also causing difficulties in the family's life. Therefore, the support of capital and the orientation of good capital use will have an impact on motivating households to well perform production and business activities, change jobs and meet the requirements of changing living environment and having New livelihood strategies meet requirements in the context of increasing integration.

\section{Acknowledgement}

The authors would like to thank the anonymous referees for constrcutive comments on earlier version of this paper.

\section{References}

Benayas, J. R., Martins, A., Nicolau, J. M., \& Schulz, J. J. (2007). Abandonment of agricultural land: an overview of drivers and consequences. CAB reviews: Perspectives in Agriculture, Veterinary Science, Nutrition and Natural Resources, 2(57), $1-14$.

Bryceson. D. F. (1996). Deagrarianization and rural employment in sub-Saharan Africa: A sectoral perspective. World Development, 24(1), 97-111

DFID. (1999). Sustainable livelihood guidance sheets, Hall- International, Inc.

GSO. (2006). Questionnaire on Household Living Standard Survey 2006 (VHLSS-2006). 
Hanoi, Vietnam: General Statistical Office.

Jansen, H. G., Pender, J., Damon, A., Wielemaker, W., \& Schipper, R. (2006). Policies for sustainable development in the hillside areas of Honduras: A quantitative livelihoods approach. Agricultural economics, 34(2), 141-153.

Le, T., Pham, V., Cu, T., Pham, M., \& Dao, Q. (2020). The effect of industrial park development on people's lives. Management Science Letters, 10(7), 1487-1496.

Nghi, N. Q., \& Van Trinh, B. (2011). Factors Affecting the Income of Ethnic Minorities in the Mekong Delta. Science Journal of Can Tho University, 18, 240-250.

Thuận, N. M., Thành, D. N., \& Nghiệp, N. T. (2018). Factors affecting household income after land acquisition for industrial parks in Vinh Long province. Journal of Science Can Tho University, 54(4b), 80-90

Nguyen.V.C et al. (2006). Agricultural land distribution in Vietnam: Emerging issues and policy implications. MPRA Paper No. 25587, University Library of Munich, Germany.

Nguyen Van Suu. (2009). Industrialisation and urbanisation in Vietnam: How appropriation of agricultural land use rights transformed farmers Livelihoods in a Per-Urban Hanoi Village?. EADN working paper.

Paul, S., \& Sarma, V. J. (2013). The livelihood effects of industrialization on displaced households: Evidence from Falta Special Economic Zone, West Bengal. ZEW-Centre for European Economic Research Discussion Paper, (13-083).

Siegel, P. (2005). Using an asset-based approach to identify drivers of sustainable rural growth and poverty reduction in Central America: a conceptual framework. The World Bank.

Tuyen, T. Q. (2013). Livelihood Strategies for Coping with Land Loss among Households in Vietnam's Sub-Urban Areas. Asian social science, 9(15), 33-46

Tuyen, T. Q., \& Van Huong, V. (2014). The impact of land loss on household income-The case of Hanoi's sub-urban areas, Vietnam. International Journal of Business and Society, 15(2), $339-358$

Tuyen, T. Q., Lim, S., Cameron, M. P., \& Huong, V. V. (2014). Farmland loss and livelihood outcomes: a microeconometric analysis of household surveys in Vietnam. Journal of the Asia Pacific Economy, 19(3), 423-444.

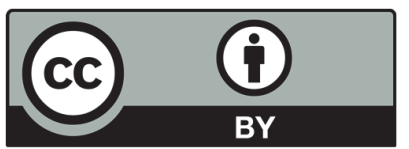

(C) 2020 by the authors; licensee Growing Science, Canada. This is an open access article distributed under the terms and conditions of the Creative Commons Attribution (CC-BY) license (http://creativecommons.org/licenses/by/4.0/). 